Article

\title{
Supermarket-Led Development and the Neglect of Traditional Food Value Chains: Reflections on Indonesia's Agri-Food System Transformation
}

\author{
Thomas Vetter ${ }^{1, * \mathbb{D}}$, Marianne Nylandsted Larsen ${ }^{2} \mathbb{D}$ and Thilde Bech Bruun ${ }^{2}$ \\ 1 Anthropology Institute, University of Neuchâtel, 2000 Neuchâtel, Switzerland \\ 2 Department of Geosciences and Natural Resource Management, Section for Geography, University of \\ Copenhagen, 1958 Frederiksberg C, Denmark; mnl@ign.ku.dk (M.N.L.); thbb@ign.ku.dk (T.B.B.) \\ * Correspondence: thomas.vetter@unine.ch; Tel.: +41-(0)32-718-1645
}

Received: 21 December 2018; Accepted: 16 January 2019; Published: 18 January 2019

check for updates

\begin{abstract}
The rapid expansion of modern food retail encapsulated in the so-called 'supermarket revolution' is often portrayed as a pivotal driving force in the modernization of agri-food systems in the Global South. Based on fieldwork conducted on horticulture value chains in West Java and South Sulawesi, this paper explores this phenomenon and the concerted efforts that government and corporate actors undertake with regard to agri-food value chain interventions and market modernization in Indonesia. The paper argues that after more than 15 years of 'supermarket revolution' in Indonesia, traditional food retail appears not to be in complete demise, but rather adaptive and resilient to its modern competitors. The analysis of local manifestations of supermarket-led agricultural development suggests that traditional markets can offer certain advantages for farmers over supermarket-driven value chains. The paper further identifies and discusses two areas that have so far been neglected by research and policymaking and which warrant further investigation: (i) the simultaneous transformations in traditional food value chains and their relation to modern markets, and (ii) the social and environmental performances of modern vis-à-vis traditional food value chains.
\end{abstract}

Keywords: value chains; development; supermarkets; traditional markets; Indonesia

\section{Introduction}

The modernization of agri-food systems in the Global South, depicted through the rapid rise of supermarkets [1-3], has shifted the attention of academia and political decision-makers away from what is commonly referred to as 'traditional' and 'informal' food retail markets to the prospects of modern food retail and the notion of (higher?) 'value chain agriculture' (for a critical evaluation of this term see [4]). The now dominant supermarket-led development paradigm prescribes that smallholders must 'upgrade' and adapt to the new requirements set forth by the corporate food sector, not only to avoid being driven out of production altogether, but rather to be able to reap the benefits of modern market participation $[5,6]$.

Such inferences also emerge from broader analytical work on rural transformation and the determinants of inclusive regional development in the Global South [7-10]. These studies suggest that while urbanization and the growing importance of non-farm activities are transforming rural livelihoods and landscapes both spatially and structurally, it is the response of rural areas to the globalization of agri-food systems that is increasingly reshaping agricultural sectors and development prospects. Access to 'dynamic markets' - be it through export or domestic agri-food value chains-is thereby considered a critical success factor and has become a paramount objective in policy formulation and development practice. 
In this context, agri-food value chain intervention strategies have flourished amongst major international development organizations and state agencies in the Global South [11-13]. Chain intervention strategies are often perceived as a way of addressing new opportunities and challenges stemming from increasing requirements regarding food safety and quality and/or restoring the link between smallholders, agri-food processors, and more remunerative markets $[14,15]$. The instrumental means entail improving vertical coordination in the value chains and strengthening the weakest link, mostly identified in the smallholder segment of agri-food value chains, to address, for example, potential quality or quantity 'blockages' (see also [11,16]).

However, empirical evidence about the prospects of modern market participation and value chain interventions remains ambiguous at best. The 'supermarket revolution', for instance, is happening much slower than previously assumed $[17,18]$, and it is usually only the asset-rich farmers who are able to make the 'supermarket grade' [19-22]. More importantly, supermarket-driven agri-food value chains are only one of the many forces affecting the transformation of agri-food systems in the Global South and they do not evolve or operate separately from the so-called traditional food sector. Whether in Latin America, Africa or Asia, traditional markets still dominate and grow in parallel with the modern food retail sector [23]. Despite this, very few studies provide counter narratives emphasizing, for example, the exaggeration or 'myopia of the supermarket revolution theory' (to paraphrase Abrahams [24]; see also Humphrey [17]) or the functions fulfilled by traditional markets and food value chains to support the livelihoods of asset-poor farmers and to ensure food security for a growing number of urban poor consumers [18,23,25-27].

Taking stock, we find that most of the literature takes its point of departure from economics-inspired framings around welfare effects on the farm level and chain-inspired analysis around unequal power relations by drawing on the global value chain (GVC) framework (see, for example, Dolan \& Humphrey [28]). Consequently, the debates revolve narrowly around farm households and entry barriers in modern agri-food value chains and exclusionary dynamics caused by more demanding food safety and quality standards imposed by leading retailers or branded manufacturers in the North. Traditional food value chains are rarely studied in this overall context of globalization and agri-food restructuring in the Global South. This paper aims to problematize this research gap by pinpointing some of the socio-economic and environmental implications of the dominant supermarket-led development paradigm, which, we argue, require more thorough examination.

The paper draws on fieldwork conducted on the horticulture value chains in West Java and South Sulawesi, Indonesia and discusses the dynamics behind the transformation of the country's agri-food system. Our analysis demonstrates the protracted nature of the supermarket revolution in Indonesia, and further highlights the concerted efforts and struggles that government and corporate actors are willing to undertake within processes of value chain interventions and market modernization. Based on an analysis of local manifestations of supermarket-led agricultural development, we point out 'blind spots' in research and policy on sustainable transformation of agri-food systems. These include greater attention to (i) the transformations of modern and traditional food value chains, simultaneously and in relation to each other, and (ii) the social and environmental performances of modern and traditional food value chains.

Our argument is structured as follows: Section 2 provides a critical appraisal of the theoretical foundations that have led to the current focus on supermarket-led development and associated value chain intervention strategies; Section 3 presents the methodology and introduces the Indonesian case study context, before turning to the country-specific expressions of the 'supermarket revolution' in Section 4.1; in Section 4.2, the local manifestations of smallholder-supermarket linkages are presented and further discussed in Section 5 against the backdrop of traditional food value chains and neglected sustainability aspects; finally, Section 6 concludes with recommendations for future value chain analyses and interventions that are more sensitive to the complex social-ecological systems in which they are embedded. 


\section{Supermarket-led Agricultural Development}

Pioneered by agricultural economists Thomas Reardon and Peter Timmer, several studies have argued that developing countries' food systems have undergone significant changes since the advent of globalization in the 1970s [1,6,29]. What began with public investments into the modernization of wholesale markets and processing industries made way for trade liberalizations and private sector investments, especially in the food retail sectors, allowing supermarkets to capture increasing sales shares [1]. Several supply- and demand-side factors have been identified as triggers behind this development, paving the way for the so-called 'supermarket revolution' [30] (p. 400). The rapid expansion of modern food retail in Latin America, Asia, and Africa and especially the hereby induced modernization of procurement systems form the key concern in the academic debate about the effects of this ongoing phenomenon on poverty: 'A hypothesis underlying the debate is that the transformation is expected to be potentially excluding of small and/or asset-poor farmers without the capacity to respond to requirements of quality, consistency, volume, and transaction specifications demanded by the modern food industry' [1] (pp. 1717-1718).

Notwithstanding such concerns, the same camp of researchers has also spotted many opportunities arising from this development. For example, empirical evidence from the horticulture sector in Kenya suggests: higher yields, prices and profits [21]; positive impacts on farm productivity [31]; beneficial spillover effects on labor markets, especially for women [32], (see also [21]); and 'substantial income gains' [19] (p. 1262) (see also [22]) for farmers participating in supermarket value chains. Similar results were also reported from other case study contexts: in Nicaragua, Michelson [33] and colleagues [34] found increases in supermarket farmers' productive assets and less price volatility, respectively; and higher yields were reported for supermarket farmers in Guatemala [20] and in China, where supermarket farmers' incomes increased as well [35].

Unsurprisingly, these benefits associated with the supermarket revolution have been embraced almost unanimously by development organizations and governments, making supermarkets the preferred tool for modernizing developing countries' agri-food systems [36]. This has become evident from the widespread adoption of value chain-inspired intervention strategies aimed at integrating poor farmers into modern or so-called 'high-value' food markets, including in Indonesia [12]. In addition, moving up the 'value-added ladder', or in other words 'upgrading' in supermarket-driven agri-food value chains, has become instrumental in the transformation of rural areas in the Global South. Pioneered by Gereffi [37], upgrading refers to the opportunities for producers in the Global South to make better products more efficiently and with more skilled work. Typically, the upgrading process is examined through the lenses of how knowledge and information flow within value chains from so-called lead firms to their suppliers or buyers. Upgrading has therefore often been analyzed in terms of the sequence and implicit hierarchies in the acquisition of functional capabilities, with the empirical focus on processes by which producers scale the value-added ladder, either by moving up to more rewarding functional positions within chains or by making more value-added products. Humphrey and Schmitz [38] emphasize that distinct types of upgrading in a particular GVC are dependent on the nature of the relationships that prevail between actors in the GVC and 'different forms of chain governance have different upgrading implications' [38] (p. 1023). These authors suggest a more concise definition of upgrading based on a fourfold categorization of upgrading: process upgrading takes place when a product is produced more efficiently by reorganizing the production system or introducing superior technology, product upgrading when production results in a product with a higher unit value, functional upgrading when production expands in terms of scope and activities, and inter-sectoral upgrading when acquired competences in one GVC are applied in a different GVC [38].

Analyzing governance is crucial to understanding upgrading trajectories in GVCs, as some forms of governance promote or reduce upgrading potentials. Several agri-food GVC studies discuss how lead firms facilitate or restrict the prospects for upgrading of small-scale producers and agri-food processors in retailer-driven GVCs [28,39,40]. Product and process parameters (e.g., food safety and quality standards) imposed by northern retailers force exporters and producers in the Global South 
to acquire a range of new capabilities to retain their relationships. This increases entry barriers to smaller and more poorly resourced companies or farmers and has resulted in a significant reduction of smallholder involvement in the export sector.

Strategies for gaining access to and upgrading within agricultural value chains have been adopted by almost all major multilateral donor agencies during the last decade-with associated strategy papers published by international development agencies with a value chain focus [15,41]. Value chain intervention strategies have also proliferated amongst state agencies in the Global South. Following the structural adjustment era with its emphasis on market liberalization and limited state interventions, new heterodox models of development thinking prevail. These are grounded in the contemporary era of economic globalization and international trade, where global competition is transmitted to domestic markets in developing countries [11]. The adaptation of value chain-inspired development projects seems to be based on an implicit, linear perception: once entry is gained by producers in developing countries, learning effects take place within the value chains and linkages between key actors in the chain embody the capacity for supply chain management and upgrading. Hence, the pivotal 'question is not if, but how to integrate in value chains' (Altenburg cited in Gereffi [11] (p. 26)) and the notion of upgrading has become a powerful diagnostic tool for identifying constraints along agri-food GVCs. The prevailing narrative stresses competition and the free market as being desirable for the welfare of agricultural producers in the Global South, and (international) lead firms as conduits of development assistance through the dynamics of firm-to-firm relationships and coordination along GVCs. The role of the state in mediating development strategies is often interpreted as the provider of a 'business enabling environment' by supporting 'market-facilitating' institutions [13] (p. 1240).

Given the more-than-private nature of agriculture and food (think: public food security, culture, identity, etc.), a potentially biased focus on supermarket-led development is highly problematic, not least because there remain considerable ambiguities and knowledge gaps with regard to the socio-economic and environmental trade-offs of supermarket-led development. Although several of the earlier discussed studies have pointed out some of the downsides of farmers' participation in modern food value chains, these seem to be disregarded in policy circles and follow-up research. Michelson et al. [34], for instance, noted no price difference for supermarket farmers in their study in Nicaragua. And the same was true for Hernández et al. [20] in Guatemala, where supermarket farmers 'actually earn slightly less per hectare than do the traditional-channel farmers' due to higher input costs, which furthermore results in the overuse of pesticides and fungicides. Fifty per cent higher rates of application of fertilizer, manure and chemicals were also noted by Neven et al. [21] in their study of Kenyan supermarket farmers. Andersson et al.'s [19] 'substantial income gains' for Kenyan supermarket farmers also appear in a different light when we learn about the high dropout rate in supermarket value chains of almost $50 \%$ in their panel data. In this case, 'access to household labor seems to be another type of capital that influences farmers' ability to supply HVM (High Value Markets)' (ibid., p. 1263) and explained why it was mostly smaller households with fewer family members and less time that had dropped out. All these are noteworthy and important observations, hinting at the hidden costs involved in supplying modern food retailers. To these also belongs the mediating role of NGOs, for example, which were mentioned to be involved in several studies, and which in one way or another help to subsidize modern market development (e.g., reducing transaction costs, technical advice). As long as these hidden costs are not adequately accounted for, however, we will only have a distorted picture, in which traditional food value chains with less and less support will obviously perform worse.

\section{Materials and Methods}

The empirical material informing our argument derives from a two-step case study that has led us first to West Java and subsequently to the district of Bantaeng in South Sulawesi (Figure 1). The case study defined as 'an empirical inquiry that investigates a contemporary phenomenon within its real-life context' [42] (p. 13) is the most suitable approach to critically engage with the research field 
introduced in Section 2 and to contribute to its further refinement. A qualitative case study approach is widely recognized to be "capable of generating a robust, comprehensive array of "knowledge" about complex, highly inter-dependent and dynamic economic and social phenomena' [43] (325) —in our case the transformation of agri-food systems in Indonesia and its local manifestations. Field work in connection with this study was carried out between April and July 2013. Primary data was collected from key stakeholders through interviews and observations during several site visits, which we have detailed below. The exact number and type of research participants was not pre-determined, and the overall field work strategy was deliberately kept flexible to allow for the exploration of upcoming issues along the way. The rationale behind this approach was not to quantify any of the observations made, or to conduct a full value chain analysis, but to qualitatively assess the information obtained against the wider, multi-scalar process of value chain restructuring in Indonesia.
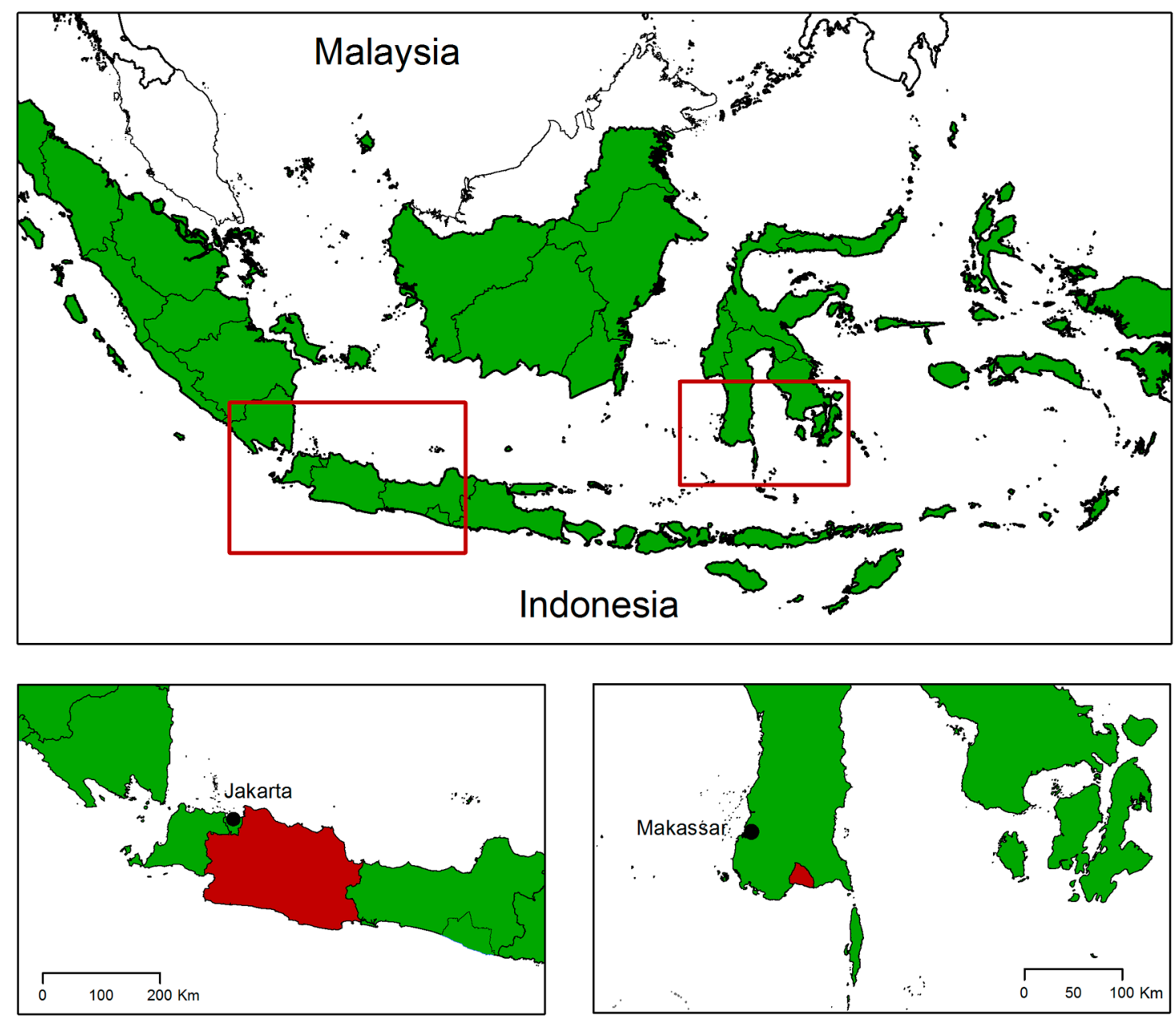

Figure 1. Map showing the two study sites of West Java Province and Bantaeng District in South Sulawesi, Indonesia.

\subsection{Research Phase 1: West Java}

The province of West Java was chosen as an entry point for data collection due to its benchmark status in national food market developments in general and horticulture production in particular. Apart from the metropolitan area of Jakarta, the diffusion of modern food retail has progressed most widely within this province and about a third of Indonesia's fruits and vegetables are produced here [44,45]. The Center for Agrifood Policy and Agribusiness Studies (CAPAS) at Padjadjaran University in Bandung was chosen as a local research partner. Such an affiliation was necessary to fulfil the legal requirements to conduct fieldwork in Indonesia and also proved useful to facilitate 
access to the field. Our sampling strategy followed the principles of snowballing and benefited from a first exploratory interview with the director of CAPAS, who had been involved in earlier research studies on related topics [44,45]. This person provided us with the contact details of five additional interview partners, who in turn connected us with seven further respondents. The total of 13 key informants were all visited and interviewed in person and included three academic experts, a manager from a specialized supermarket wholesaler, three experienced supermarket farmers, one civil servant involved in horticulture research, three staff members from different certifying bodies (i.e., organic and other standards), and one staff member each from a multilateral organization and a transnational farmers organization. All interviews were conducted with the aid of an interview guide that entailed a set of questions about food retail structures and developments, procurement practices, and conditions for smallholder horticulture producers in order to triangulate all information obtained. In addition, more specific questions relating to the job position of each respondent were asked.

Some of our interview partners did not only function as informants but also became important gatekeepers offering access to research assistants and facilitating visits to relevant field sites, including seven modern and five traditional food retail outlets. These visits provided additional insights and opportunities for informal conversations with staff members and traders. Such important tacit knowledge was acquired through participant observation that not only benefitted the depth of our data, but specifically helped us to clarify the room for interpretation of all other information obtained. In this sense, participant observation became employed as an additional data collection method and as a tool for simultaneous data analysis [46]. The combined insights from both activities served the purpose of assessing previous research findings and published statistics against an in-situ reality check.

\subsection{Research Phase 2: South Sulawesi}

The second and longer part of the fieldwork concentrated on the dynamics in the district of Bantaeng. This district is located on the southern coastline of South Sulawesi and covers an area of $400 \mathrm{~km}^{2}$ with a population of 176,700 [47]. Previous studies on supermarket development and horticulture production in Indonesia focused almost exclusively on Java $[44,45,48,49]$. By choosing Bantaeng as one of the main study areas, it was possible to go beyond this scope and investigate how far the developments in the Indonesian "periphery" differ from "the centre". South Sulawesi is a good place to start with, because it is the economic heart and trade hub of Eastern Indonesia-a region which traditionally lags behind the economic development of Java or Sumatra. The provincial capital Makassar ( 1.3 million inhabitants) is one of the most rapidly growing urban areas in Indonesia with a thriving middle class that represents a potential consumer base for modern food retail. The district of Bantaeng was purposely selected due to its portrayal in national media as a successful example of rural transformation [47]: The special report 'Prospering from Agrobusiness' published by the Indonesian weekly journal Tempo described how Bantaeng had transitioned from a lagging agrarian-based economy to a relatively prosperous and diversified one. An important pillar of this was the integration of agricultural producers into modern food value chains both in domestic and export markets. The agricultural sector still makes up 50\% of Bantaeng's economy and employs roughly three-quarters of the district's population. Thus, with an institutional environment dedicated to connecting its horticulture farmers with dynamic markets, Bantaeng provides a particularly interesting case for gaining a deeper understanding of the politics behind and experiences with local supermarket-led development in an era of globalization.

As in research phase one, we established an affiliation with a local research institute (Hasanuddin University in Makassar) as a first entry point to the field. Again, all sites and respondents have been identified through snowballing starting with those academic key informants and some of the actors that were mentioned in the Tempo news article. We continued our data collection with site visits to five modern and four traditional food retail outlets and 25 semi-structured interviews with academics, government officials, input merchants, procurement managers, supermarket farmers, traditional farmers, intermediary traders, and processors. As in West Java, the interviews were guided by a similar 
set of questions regarding food retail structures, procurement practices, and conditions for smallholder horticulture producers in South Sulawesi. They were supplemented with additional questions relevant to the local context such as the role of government support at the provincial and district levels.

Through this iterative approach, we learned about a local government-driven marketing initiative that was set up in 2011 with the stated objective to supply modern food retail outlets in Makassar with produce from Bantaeng. In order to capture the experiences with this project and the market relations of Bantaeng's horticulture producers more generally, we carried out structured interviews with the chairmen of 10 farming groups. Those were selected from a list of all the farming groups involved in the aforementioned initiative and which were primarily producing fresh fruits and vegetables. We decided to interview the chairpersons of these farmer groups as they were expected to be able to provide an in-depth account of the experience of their respective farmer group, in addition to their own individual experience as farmers. The questionnaire contained closed and open-ended questions about the characteristics of the farm, the farmer's socio-economic background, their crop management practices, and their experiences with supermarket buyers and traditional traders. A farm walk concluded each interview and provided additional insights and opportunities to explore some of the issues raised during the interview in more detail.

All research participants in South Sulawesi and West Java were visited at their premises and according to their time preferences. Prior to each interview, the respondents were informed about the purpose of the research. To guarantee their anonymity, we only provide their job title, the location and the number of the interview in the remainder of this article. While the semi-structured interviews lasted between 20 minutes and two hours, each questionnaire with a farmer took between three to five hours. Semi-structured interviews were recorded with an audio device in situations deemed appropriate; in other circumstance, notes were taken and later summarised. Important in this context were the personal capabilities of our interpreters, who helped to bridge language gaps and cultural barriers. Translations from either Bahasa Indonesia or from one of the local dialects to English were required for all the questionnaires and for most of the semi-structured interviews. Only few respondents were able to communicate in English. The answers obtained from farmers were directly noted in the questionnaire by the researcher after being translated by the interpreter. This helped to avoid ambiguity and also allowed to probe into new issues.

Lastly, it is important to note that the two study areas should not be misread as comparative cases; rather, they each represent important points of reference for market- and production-related developments in a country as heterogenous as Indonesia. This overall study sample has of course its weaknesses, as it only represents a relatively small population of respondents. However, due to the exploratory and qualitative nature of this study, it was found appropriate and very useful for embedding the developments observed in both study areas within the wider research context. In doing so, it was possible to identify some of the blind spots that previous research on the transformation of agri-food systems has left unaddressed.

\section{Results}

\subsection{Indonesia's Protracted Supermarket Revolution}

The transformation of Indonesia's agri-food system has previously been described as a textbook example substantiating the notion of the 'supermarket revolution' in the Global South $[44,45,48]$. In accordance with the experience of other Southeast Asian countries, modern food retail hardly existed in Indonesia until the end of the 1990s [1,3]. This changed with the onset of the Asian financial crisis in 1997/98, the downfall of the authoritarian Suharto regime, and the ensuing democratization and economic liberalization processes, which opened the domestic market to foreign direct investments by food retail transnational corporations. Alongside other favorable macroeconomic supply- and demand-side developments (e.g. deregulation, economic growth, urbanization, rising incomes), the market entry of Western food retail giants such as Walmart, Carrefour, Ahold and Makro 
represented an important impetus for growth [44]. Consequently, Indonesia's modern food retail sector grew from a very low level in 1999 to more than 26,000 outlets with a combined sales value of USD 16.3 billion in 2014 [50] (see also Figure 2).

However, of these, around 24,000 outlets fall into the category of convenience stores, which carry a very small range of fresh food products, as compared to supermarkets and hypermarkets; and instead of an expected dominance of Western food retail chains, second-tier transnational corporations from other Asian countries, and especially Indonesian-owned retail chains, have been able to capture and/or retain market shares in what classifies as a highly competitive, but still small and unconsolidated, market environment. These trends are clearly reflected in the market entry of the Korean-owned Lotte Mart in 2008 and in the acquisition of Carrefour's Indonesian outlets by the domestic conglomerate CT Corp in 2012 [51,52].

Thus, besides competitive regional and domestic investments, the successful introduction of new retail formats must be seen as the key driver: initially hypermarkets, and later on convenience stores in particular, have spearheaded the expansion of modern food retail across the Indonesian archipelago following a typical urban-to-rural diffusion pattern. After penetrating the metropolitan areas on Java, the retailers are expanding on the other main islands [44,53].

Apart from this geographic expansion, a socio-economic diffusion has set in, bringing with it growing market segmentation and product differentiation. This has already progressed relatively far as several leading grocery retail chains seek to broaden their consumer bases. For example, a growing selection of niche market products, including certified and non-certified organic foods, are available for the more affluent and/or conscious consumers; private label products are used to attract more price-sensitive customers; and special promotion events such as Carrefour's so-called 'cheap market events' are specifically designed 'to help out low income people' [54]. In this context, fresh food products, including fruits and vegetables, have become an important factor for growth. Indonesians still prefer to buy these products in the traditional markets, but through competitive pricing, a diverse product variety, and uniform quality, modern retailers are trying to lure more customers into the unknown supermarket territory.

All in all, the growth story of modern food retail in Indonesia certainly looks impressive, both on the ground and in figures, but it masks important counterfactuals when compared to the traditional food retail sector. As illustrated in Figure 2, modern food retail only accounts for a small fraction of the total food retail sales within the country. With USD 83.2 billion out of a total of USD 99.5 billion in 2014, more than $83 \%$ of the market is left in the hands of traditional retailers-comprising wet markets, food stalls, kiosks and street vendors [50]. Thus, after more than 15 years of 'supermarket revolution', traditional food retail appears not to be in complete demise, but rather adaptive and resilient to its modern competitors. Although the number of traditional outlets is stagnating at a very high level, the overall sales value of traditional grocery retailers has been increasing, for example by $59 \%$ between 2009 and $2014[50,55]$. 


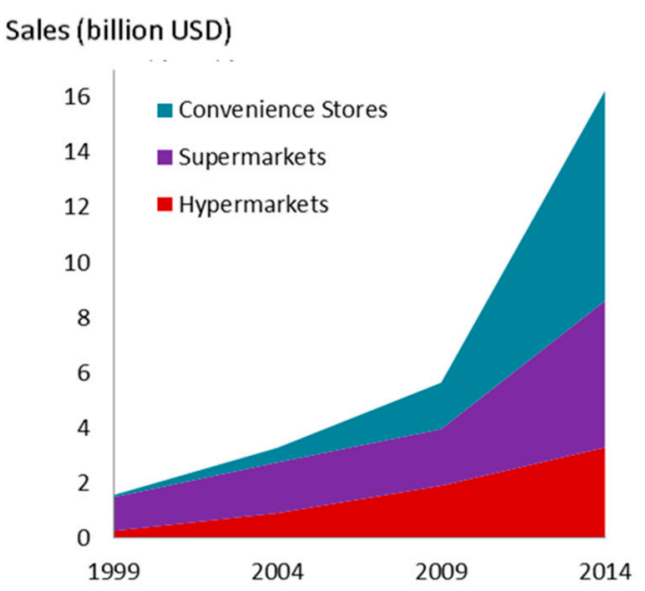

(a)

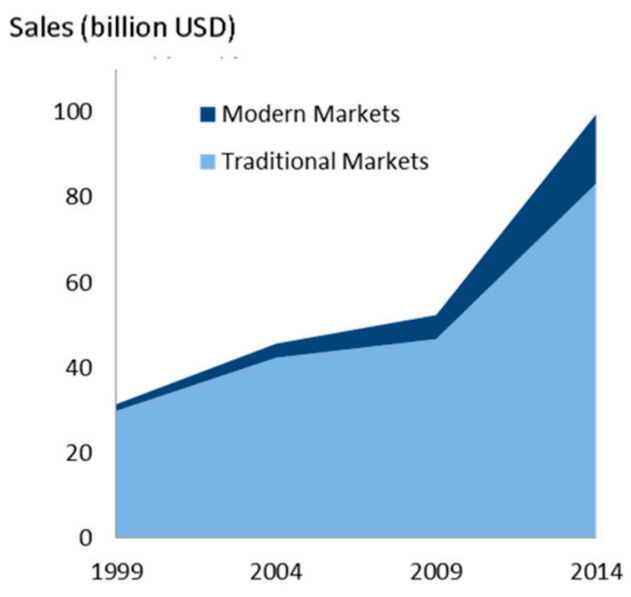

(b)

Figure 2. Development of food retail sales in Indonesia by modern market channel (a) and compared to the traditional food retail sector (b), 1999-2014 (sales in billion USD). Source: Dyck, Woolverton, \& Rangkuti, [56] (p. 12) for 1999-2009 data; Euromonitor [50,55] for 2014 data.

Despite the protracted nature of the 'supermarket revolution' and the remarkable resilience of traditional markets, Indonesia's domestic horticulture sector has increasingly come under pressure from rising imports originating from other emerging countries. In particular, exports from China are flooding the Indonesian market with about $55.7 \%$ of all fresh fruit imports and $70 \%$ of fresh vegetables [57]. FAOSTAT [58] figures indicate a tremendous rise in imports during the second half of the 2000s and show that these imports are no longer limited to temperate fruits or vegetables alone. Today, even tropical crops such as chillies, bananas, and mangoes are imported in larger quantities, with potentially adverse effects on local production.

Indonesia's modern food retailers certainly contribute their fair share to this development as they are 'highly efficient "Trojan horses" of imported goods' [30] (p. 416). Natawidjaja et al. [44] found that compared to other developing countries, Indonesia's modern food retailers show a much higher reliance on imported fresh fruits and vegetables due to perceived quality differences. This was confirmed again in our interviews with procurement managers in Makassar, who emphasized that standard sizes, consistent colors, freshness and lower spoilage rates were important criteria that made imports look more attractive to them and furthermore allowed the retailers to make cost savings and specific items available during the off-season (e.g., procurement manager, Makassar 17, personal communication, 16 May 2013). However, it needs pointing out that a large percentage of these imports enters the country's traditional wet markets, not only due to procurement linkages with the modern food retail sector, but also because of the overall changing dietary habits of Indonesian consumers more generally.

The following section presents how the above transformations and challenges play out in Bantaeng, South Sulawesi. We first examine how local government authorities have embraced value chain intervention strategies to promote linkages between smallholders and supermarkets as a means to upgrade and 'couple' smallholders to more remunerative markets. This is followed by an examination of the modern retailers' own efforts to source directly from farmers.

\subsection{Local Manifestations of Supermarket-led Agricultural Development}

\subsubsection{State-led Coupling and Decoupling}

In response to the perceived underperformance of domestic horticulture supply chains and the growing imports of fruits and vegetables, the Indonesian government temporarily imposed import bans [59] and launched several nationwide initiatives to promote the consumption and production of domestic fruits and vegetables. Besides public campaigns encouraging consumers to buy more local 
produce, funds have been made available, specifically for the establishment of links between farmers and modern food retailers. These funds are administered by the Directorate General of Processing and Marketing of Agricultural Products-a subunit of the Ministry of Agriculture-which has been mandated with the promotion of Indonesian agricultural products through improvements in marketing and standardization (civil servants, Makassar 14 \& 15, personal communication, 15 May 2013).

Within this context, the provincial government of South Sulawesi secured funding from the national budget and collaborated with the local authorities in Bantaeng to initiate a collective marketing project with the formation of the farmer group association Maju Mandiri in 2010. The basic idea behind this state-led modern market access initiative was the direct delivery of organic fruits and vegetables and other agricultural products from Bantaeng to modern retail outlets in Makassar. These outlets have emerged in the provincial capital of South Sulawesi since the mid-2000s, but still continue to rely on imports from abroad and from West Java for most of their fruit and vegetable supplies, due to the perceived quality constraints.

Altogether 17 farmer groups were selected for this project comprising mainly fruit and vegetable producers from the high- and lowlands, as well as a few producers of staple foods (i.e., rice and corn) and processed foods (i.e., dried chilies and snacks). The latter included a newly founded women's group, engaged in the small-scale production of snacks made from local products such as carrot crisps. True to its motto of 'do-it-yourself development' (as Maju Mandiri loosely translates), the association was endorsed with the responsibility for the daily operation and management of facilities. The project had been equipped with a refrigerated delivery truck (3-ton capacity), another vehicle for transportation of inputs and harvests, and a cold-storage warehouse (30-ton capacity) including office space and packing facilities, all constructed in the center of Bantaeng town next to the main road.

Through this project, the government authorities have sought to tailor the district's horticulture production to the needs of supermarkets in Makassar through collective action and by taking several upgrading steps at the same time. From the start, a mediating role was maintained, whose underlying rationale is worth delineating in more detail. A civil servant from the Unit for Horticulture at the Provincial Ministry of Agriculture in Makassar acted as the gatekeeper and financial guarantor, establishing modern market access on behalf of the farmers in Bantaeng. The civil servant concerned thereby entered into a contract with the retailer as a private supplier holding all rights and responsibilities. According to another respondent at the ministry, this intermediary role was necessary because of the delayed payments, which are typical for supermarkets but problematic for producers: 'The farmers here they want cash, but [the retailer] is only paying every two weeks. So (civil servant, Makassar 14) is acting as the link' (civil servant, Makassar 15, personal communication, 15 May 2013).

The outcome of this project shows, however, that government intermediation was not sufficient. Maju Mandiri started to supply the retailer's outlets in Makassar in 2011, but the deliveries were stopped after only six months for several reasons. First, the participating farmer groups felt inadequately included in the planning and management of the project. For example, the acquisition of modern equipment and facilities was done without assessing the farmers' needs. Many of them regard the cold-storage room in the town as an unnecessary investment, because once the produce had been transported down to the main road of Bantaeng, it could also have been immediately transferred on to Makassar. Storage as such did not provide farmers with any benefits. On the contrary, they perceive it as a waste of time and money, as they would have been required to pay for the storage of their products, which would then have reduced their profits. The counter-argument of the local authorities that the storage facility would help the producers to bridge income losses during times of lower prices (civil servant, Bantaeng 25, 13 June 2013) runs short of the fact that most of the products are highly perishable and not suitable for longer storage periods.

Another major constraint according to the farmers was the initial focus on organic products, without considering the fact that fully organic production was not in place. This meant that the government authorities and the retailers basically expected the farmers to be able to produce and deliver high-quality organic products from scratch, as the following résumé of one of the farmers 
recalling his experience with the project illustrates (farmer, Bantaeng 8, personal communication, 23 June 2013). He reported that the retailer came to see him in 2011 together with the Department of Agriculture in Bantaeng and asked him to supply organic chilies. They offered him a higher price and the trading process would be done through Maju Mandiri. A delivery car and storage room would be used. However, he could not fulfil their requirements as they wanted a consistent quality of bigger chilies with a straight shape, which he found very difficult to achieve, especially in organic production.

These quality constraints were not only a problem in chili production, but a common issue among all participating farmer groups. Thus, after several attempts, the retailer eventually stopped the cooperation because the delivered products did not meet the retailer's quality standards according to the civil servant responsible for the project at the Department of Agriculture in Bantaeng (civil servant, Bantaeng 25, 13 June 2013). Given that meeting modern quality standards is already a challenge in conventional agricultural production, the focus on organic niche markets right from the beginning was certainly well intended but condemned to failure. As a result of the many shortcomings, the project has been on hold since 2011, leaving all the equipment and facilities unused and the modern supplier group dysfunctional.

\subsubsection{Supermarket-led Coupling and Decoupling}

Apart from such chain intervention strategies led by state authorities, modern food retailers in Makassar also seek to establish direct relations with horticulture producers from Bantaeng and other districts in South Sulawesi. As there are no specialized modern wholesale companies (in contrast to West Java), this is the only option they have to decrease their dependence on the traditional wholesale markets as well as on imports from Java or from abroad.

Due to its closer proximity to Makassar and its leading productivity level in South Sulawesi, the horticulture production zone in the highlands around the town of Malino had attracted the attention of modern procurement managers earlier than Bantaeng. In the area, there are more than 1000 farmers organized in farmer groups cultivating around 4000 ha of land. One of these groups used to supply three large retailers in Makassar for a period of about two years, but voluntarily opted out of the modern market in 2010 for the following reasons.

According to the head of the farmer group (farmer, Malino 32, personal communication, May 2013), the supermarkets approached him independently and agreed over the conditions of supply in the form of a written memorandum of understanding (MoU). This MoU did not have a fixed duration and prices were determined every week. Listing fees or penalties were not imposed and neither did the $\mathrm{MoU}$ require the group to pack the products themselves. However, a continuous supply of consistent quality and quantity was expected to be delivered by the group to the outlets each morning at 08:00 $\mathrm{am}$. Yet, despite these contractual agreements, the supermarkets very soon started to demand packing as well. But since the prices paid for the products were only slightly higher than in traditional markets, this additional requirement made the arrangement unprofitable for Malino's farmers group. Moreover, the group had never been completely satisfied with the modern market arrangements in the first place, because it cultivates a range of 30 different products, while the modern markets only requested 18 . This meant they still had to uphold their relationships with the traditional markets in order to sell their remaining produce. This is particularly noteworthy, as the literature usually emphasizes that modern markets require a larger product variety than traditional farmers are able to provide [5] (p. 31). This example shows that the problem can be reversed too.

In Bantaeng, none of the farmers we interviewed supplied modern markets at the time of the research, but some of them had been approached by modern retailers in the past or were negotiating to supply them in the near future. Typically, these belonged to the upper spectrum of farmers: i.e. the asset-rich (e.g., in land and labour); those chairing the local farmer group; and those with well-established relations with civil servants and traditional market traders. One of these farmers (farmer, Bantaeng 6, personal communication, 21 June 2013), for example, was approached by one of Indonesia's largest retailers with the request to supply avocados for their outlets in Makassar. 
Both parties entered into an MoU stipulating the payment procedures and delivery responsibilities. The MoU foresaw biweekly payments with deliveries being handled by the retailer. While the first batch of $300 \mathrm{~kg}$ of avocados had then been picked up as agreed, with the second delivery $(350 \mathrm{~kg})$ the retailer was already demanding that the farmer should take over the task of delivery. Despite their differing original agreement, the farmer agreed to the request a few more times as the retailer paid a slightly higher price than on the traditional wholesale market (approx. IDR $1000 / \mathrm{kg}=$ about US Cents 9 at the time of the research). However, after the biweekly payments also started to be delayed, the farmer finally stopped his supplies, whereupon the MoU got annulled. Despite this negative experience, the farmer would still consider supplying the modern market, provided that conditions were better than last time.

Negotiating better conditions can take a long time, as a final example from Bantaeng shows (farmer, Bantaeng 5, personal communication, 20 June 2013). It furthermore demonstrates the involvement and mediating role that civil servants continue to play in the identification and process of selection of suitable supermarket farmers. In this case, the farmer received a visit at the end of 2012 from the procurement manager of a large retailer in Makassar, who was accompanied by a public servant from the Department of Agriculture in Bantaeng. The duo offered him the opportunity to become a direct supplier of potatoes. However, the conditions proposed in the first offer were far from attractive: the proposed price was only slightly higher than in the traditional wholesale market Pasar Terong in Makassar (IDR 6000 instead of IDR 5000 per kg potatoes); sorting, washing, packing and direct delivery were expected from the farmer; and the resulting price difference of IDR 1000 was simply not enough to break even. Consequently, the farmer rejected this first offer. At the time of research in mid-2013, the farmer was still in a bargaining process with the procurement manager, who continued to call. Just like in the previous example, the farmer also belongs to the upper spectrum of farmers in Bantaeng. In fact, he owned the largest area of land (10 ha), was able to hire 20 seasonal laborers, and earned the highest household income in our sample.

\section{Discussion}

In line with most of the literature, the benefits and constraints of smallholder participation in modern food retail in Indonesia so far remain too inconclusive for broad-based generalizations. Instead, the narrative above urges us to pay more attention to the dynamic nature of traditional markets and food value chains. In the remainder of this paper, we point out two issues that we see emerge from our case material.

First and in marked contrast to the literature, voluntarily opting out of supermarket supply chains and instead responding to the rising demands of fresh fruits and vegetables in traditional markets proved more promising for one of the farmer groups we studied. For Malino's farmers, the cooperation with the modern market was less beneficial than that with the traditional market. It was simply more profitable and efficient to sell their products to traders who in turn benefited from increasing inter-island trade (here in particular between Sulawesi and Kalimantan): profit margins were higher and the harvests could be sold in bulk instead of the more labor-intensive and tedious supply of small quantities to retail outlets in Makassar on a daily basis. The entire produce could be sold off into one market channel, thereby reducing the necessity to maintain multiple trading relationships. As a logical consequence, the group eventually decided to cancel their contract with the modern retailers-a step that the literature would usually describe with the term 'downgrading' [60].

Conversely, 'upgrading' via modern food retail markets may contain several misconceptions, which require more thorough analysis: for instance, while the literature generally perceives modern market access as going hand in hand with formalized contracts offering increased security and logically income stability for farmers [5,34], our cases exemplify that this is not necessarily upheld in reality. Formal agreements may well exist, but these, it seems, are designed to safeguard the modern retailers' interests. In contrast, those stipulations supposedly safeguarding farmers' rights may simply become 
ignored due to unequal power relations, consequently leading to more insecurity for farmers rather than less.

Participation in modern food retail markets also necessitates investments (e.g., in labor, inputs and packing facilities), which are shouldered by farmers alone in order for them to cope with more intensive production and distribution systems. The only minimally larger profit margins may then eventually get eaten up quickly, thereby casting doubts over the superiority of modern markets even in terms of financial returns. This may explain why some farmers remain hesitant about entering 'high'-value modern markets in the first place.

It appears that traditional markets continue to be attractive and offer certain advantages over modern market participation, thereby posing the question as to which way is really 'up' in Indonesia's local food economy (to paraphrase Ponte \& Ewert [60]). Given current estimates that around 85 per cent of horticulture farmers do not participate in modern markets [44], it begs the question as to how this vast majority of farmers (plus middlemen, traders, etc.) are doing in traditional food value chains. Our interviews reveal that traditional markets are far from static, but in fact adapt and respond to changing consumer demands. For example, one farmer explained that a trader from Makassar's traditional market Pasar Terong suggested to him that he should grow bell pepper and broccoli, because the trader wanted to substitute local produce for imports from Surabaya (West Java); another farmer was requested to grow low-input shallots; and yet another one founded a farmer group specializing in the booming potato growing business. Diversification, innovation and specialization could also be observed among middlemen and traders, who, according to the farmers in Bantaeng, have increased in numbers over the last ten years, bringing with them more competition and providing farmers with more choice and room for bargaining. Hence, it was common practice to maintain trading relationships with a large number of buyers (between 5 and 10), which was perceived as being beneficial in terms of risk reduction and for obtaining higher farm gate prices.

Second, systemic and longer-term implications need to enter the market-led development equation. Inclusive growth and inequality manifestations need to be addressed beyond the farm level and along both modern and traditional food value chains. Not only, for example, might increasing income disparities become manifested on the farm level due to modern market value chain intervention strategies targeting and favoring the already better-off farmers (as in our case material; see also Andersson et al. [19], for the case of Kenya), but inequalities may well be reinforced more broadly speaking through public support for modern markets and public neglect over traditional markets. In fact, a two-tier system of producers for the domestic market is crystallizing, including 'those who are big (and wealthy) enough to supply supermarkets and those (mostly peasants) who sell into traditional markets' [26] (p. 514). Further, modern food retail and potential value capture for a few asset-rich farmers does not necessarily result in 'better quality' products, compliance with food safety standards, or more sustainable food systems. One concern that has been raised in the literature is that economic upgrading and the sole focus on its financial value may come at significant costs $[16,61,62]$. In both research and practice, more emphasis should therefore be placed on the ecological sustainability of market-led development and upgrading, because value creation and more generally speaking 'all forms of production, distribution and consumption place demands on the natural environment in two major ways: in terms of inputs to the production process derived from the natural environment as resources and in terms of outputs to the natural environment in the form of pollution/waste.' [63] (p. 279).

These issues do not feature prominently in the debate about the impacts of the 'supermarket revolution' and related value chain interventions, even though earlier studies suggested that farmers who are supplying supermarkets tend to rely on more water for irrigation and overuse chemical inputs to comply with product quality requirements $[20,21]$. Upgrading to modern markets might therefore contribute to environmental degradation (e.g., biodiversity loss, soil erosion) and adverse effects on health (both human and non-human), and threaten the long-term sustainability and productivity of agro-ecosystems. This is not to say that production practices and conditions in traditional food value 
chains are better per se, but the various impacts on the natural environment need to be analyzed in a more systematic and comparative way. In fact, this should apply to environmental issues along the entire value chains, not just at the farm level: for example, post-harvest losses and food waste are well-known problems in both traditional and modern markets, but is the former less efficient than the latter?

Observations and discussions in Makassar's traditional market Pasar Terong reveal that some people may well cherish what others reject: here commercial buyers (e.g., traders, restaurants) purchase first-grade products during the night, when the fruits and vegetables are delivered to the market; in the early morning hours, housewives follow to buy second-grade products; during the daytime, mostly third-grade products are left for the poorer consumers; and what is not sold until the afternoon is taken back by farmers as animal feed or material for organic compost. The prices, of course, reflect these traditional grades (middleman, Makassar 28, personal communication, 26 June 2013). This example underlines that we should not judge these questions subjectively based on the visual impact or odor of traditional markets, or perhaps on modern retailers' ability to lock away waste more discreetly from the eyes and noses of consumers and political decision-makers. Rather, this needs to be based on more evidence about what is actually happening to waste, its avoidance, and reuse.

Returning to the adaptations of the GVC framework and its associated notions of upgrading and governance by international and national development agencies, it remains pertinent to stress that value chain interventions should not be viewed as neutral development tools. Strengthening coordination in agri-food value chains by linking smallholders and/or farmer groups to market outlets such as supermarkets inevitably interacts with local patterns of socio-economic development and relations of power. As our case material suggests, power relations are manifested, for example, through formal contracts between farmer groups and supermarkets as well as by the performance requirements imposed by supermarkets that condition inclusion and exclusion dynamics within the agri-food chains. This in turn points towards the crucial role of the specific national and local circumstances in shaping the prospects for value chain upgrading.

\section{Conclusions}

The insights above have demonstrated that the story of the inevitable march of supermarkets in the Global South is not as straightforward as it was told—certainly not in the case of Indonesia's local food economy (see also Abrahams [24] for similar observations in Zambia). While the modern food retail sector has become more relevant in size, the traditional food retail sector is far from vanishing. On the contrary, traditional food value chains appear to be competitive and attractive to farmers too. Similar caveats apply to the upgrading concept and to how it has been translated into development practice: although being instrumental to understanding value chain transformations and to acting upon them, a narrow concept linked to firm-level competitiveness and potential poverty effects on the household level ignores broader structural questions and thus lacks both analytical punch in improving our knowledge and development prospects regarding wider matters of inequality and sustainability. Thus, more comparative and systematic analyses of modern vis-à-vis traditional food value chains seem overdue before continuing to favor one development paradigm over another. In this way, chain- and node-specific social and ecological constraints are likely to emerge, which can then be investigated and compared in more detail and related to the different and changing governance structures and upgrading trajectories. This will help to broaden our understanding of the benefits and constraints in each respective market channel (as well as about the interrelations between these stylizations) and contribute to a reconceptualization of upgrading that becomes more sensitive to wider social and ecological conditions that shape and are shaped by transforming agri-food systems. This is important because supermarkets are no golden bullet, either in the Global North, where they play a key role in the development dead ends of the industrial food system, or in the Global South, where the majority of studies show that so far supermarkets have only provided a market outlet for a very small number of farmers. 
Looking back at the experiences in Bantaeng, one is inclined to ask whether the benefits of institutional and financial support measures for traditional markets would exceed those for supermarkets, or if there are other economic, social, environmental and cultural values to be retained or strengthened by supporting more diverse sectoral upgrading pathways, for example. These are open questions, but important ones, as redirecting our attention to traditional markets appears more constructive than continuing with an overemphasis on development interventions grounded in monodirectional, path-dependent development thinking, which simply runs the risk of missing out on other developments and potential trajectories that perhaps are more inclusive and sustainable. Without doubt, there is tremendous scope for NGOs, government, and even the private sector to turn their eyes to the many potentials of traditional markets and food value chains, which remain popular among the majority of local producers and consumers. A more pluralistic market-led development approach, serving the needs and demands of heterogeneous groups of society, appears more appealing and is certainly better suited to contribute to the multifunctional objectives of more sustainable agri-food systems.

Author Contributions: Conceptualization, T.V., M.N.L. and T.B.B.; Data curation, T.V.; Formal analysis, T.V.; Funding acquisition, T.V.; Investigation, T.V.; Methodology, T.V.; Project administration, T.V.; Supervision, M.N.L. and T.B.B.; Visualization, T.B.B.; Writing—original draft, T.V. and M.N.L.; Writing—review \& editing, T.V., M.N.L. and T.B.B.

Funding: The fieldwork for this research was supported by the University of Copenhagen, Oticon Fonden under grant number 13-0667, and the Fiat Panis Foundation under grant number 11/2013.

Acknowledgments: The authors would like to thank all research participants. We also thank Ronnie Natawidjaja, Rahim Darma and Imam Mujahidin for guidance during the fieldwork, and we are particularly grateful to Irlan Adiyatma, Haris Fradilla, Ade Poetra, Dewi Indriyani and Darmadi Hawani for their research assistance.

Conflicts of Interest: The authors declare no conflict of interest. The funders had no role in the design of the study; in the collection, analyses, or interpretation of data; in the writing of the manuscript, and in the decision to publish the results.

\section{References}

1. Reardon, T.; Barrett, C.P.; Berdegué, J.A.; Swinnen, J.F.M. Agrifood industry transformation and small farmers in developing countries. World Dev. 2009, 37, 1717-1727. [CrossRef]

2. Reardon, T.; Timmer, C.P.; Berdegué, J.A. The rapid rise of supermarkets in developing countries: Induced organizational, institutional, and technological change in agrifood systems. J. Agric. Dev. Econ. 2004, 1, 168-183.

3. Reardon, T.; Timmer, C.P.; Barrett, C.B.; Berdegué, J.A. The rise of supermarkets in Africa, Asia, and Latin America. Am. J. Agric. Econ. 2003, 85, 1140-1146. [CrossRef]

4. McMichael, P. Value chain agriculture and debt relations: Contradictory outcomes? Third World Q. 2013, 34, 671-690. [CrossRef]

5. McCullough, E.B.; Pingali, P.L.; Stamoulis, K.G. Small farms and the transformation of food systems: An overview. In The Transformation of Agri-Food Systems; McCullough, E.B., Pingali, P.L., Stamoulis, K.G., Eds.; FAO and Earthscan: London, UK, 2008; pp. 3-46.

6. Reardon, T.; Timmer, C.P. Transformation of markets for agricultural output in developing countries since 1950: How has thinking changed. In Handbook of Agricultural Economics; Evenson, R.E., Pingali, P.L., Eds.; Elsevier: Amsterdam, The Netherlands, 2007; Volume 3, pp. 2807-2855.

7. Berdegué, J.A.; Escobal, J.; Bebbington, A. Explaining spatial diversity in Latin American rural development: Structures, institutions, and coalitions. World Dev. 2014, 73, 129-137. [CrossRef]

8. Berdegué, J.A.; Rosada, T.; Bebbington, A. The rural transformation. In International Development: Ideas, Experience, and Prospects; Currie-Alder, B., Kanbur, R., Malone, D.M., Medhora, R., Eds.; Oxford University Press: New York, NY, USA, 2014; pp. 463-478.

9. Escobal, J.; Favareto, A.; Aguirre, F.; Ponce, C. Linkage to dynamic markets and rural territorial development in Latin America. World Dev. 2014, 73, 44-55. [CrossRef]

10. Haggblade, S.; Hazell, P.; Reardon, T. The rural non-farm economy: Prospects for growth and poverty reduction. World Dev. 2010, 38, 1429-1441. [CrossRef] 
11. Gereffi, G. Global value chains in a post-Washington Consensus world. Rev. Int. Political Econ. 2014, 21, 9-37. [CrossRef]

12. Neilson, J. Value chains, neoliberalism and development practice: The Indonesian experience. Rev. Int. Political Econ. 2014, 21, 38-69. [CrossRef]

13. Werner, M.; Bair, J.; Fernández, V.R. Linking up to development? Global value chains and the making of a post-Washington consensus. Dev. Chang. 2014, 45, 1219-1247. [CrossRef]

14. UNIDO. Value Chain Diagnostics for Industrial Development: Building Blocks for a Holistic and Rapid Analytical Tool; UNIDO: Vienna, Austria, 2009.

15. UNIDO. Pro-Poor Value Chain Development. 25 Guiding Questions for Designing and Implementing Agroindustry Projects; UNIDO: Vienna, Austria, 2011.

16. Riisgaard, L.; Bolwig, S.; Matose, F.; Ponte, S.; Du Toit, A.; Halberg, N. Integrating poverty and environmental concerns into value chain analysis: A strategic framework and practical guide. Dev. Policy Rev. 2010, 28, 195-216. [CrossRef]

17. Humphrey, J. The supermarket revolution in developing countries: Tidal wave or tough competitive struggle? J. Econ. Geogr. 2007, 7, 433-450. [CrossRef]

18. Tschirley, D.; Ayieko, M.; Hichaambwa, M.; Goeb, J.; Loescher, W. Modernizing Africa's Fresh Produce Supply Chains without Rapid Supermarket Takeover: Towards a Definition of Research and Investment Priorities; MSU International Development Working Paper, No. 106; Michigan State University: East Lansing, MI, USA, 2010.

19. Andersson, C.; Chege, C.; Rao, E.; Qaim, M. Following up on smallholder farmers and supermarkets in Kenya. Am. J. Agric. Econ. 2015, 97, 1247-1266. [CrossRef]

20. Hernández, R.; Reardon, T.; Berdegué, J. Supermarkets, wholesalers, and tomato growers in Guatemala. Agric. Econ. 2007, 36, 281-290. [CrossRef]

21. Neven, D.; Odera, M.M.; Reardon, T.; Wang, H. Kenyan supermarkets, emerging middle-class horticultural farmers, and employment impacts on the rural poor. World Dev. 2009, 37, 1802-1811. [CrossRef]

22. Rao, E.; Qaim, M. Supermarkets, farm household income, and poverty: Insights from Kenya. World Dev. 2011, 39, 784-796. [CrossRef]

23. Vorley, B.; del Pozo-Vergnes, E.; Barnett, A. Small Producer Agency in the Globalised Market: Making Choices in a Changing World; IIED: London, UK; HIVOS: The Hague, The Netherlands, 2012.

24. Abrahams, C. Transforming the region: Supermarkets and the local food economy. Afr. Aff. 2009, 109, 115-134. [CrossRef]

25. Benson, E.; Best, S.; del Pozo-Vergnes, E.; Garside, B.; Mohammed, E.Y.; Panhuysen, S.; Piras, G.; Vorley, B.; Walnycki, A.; Wilson, E. Informal and Green? The Forgotten Voice in the Transition to a Green Economy; IIED Discussion Paper; IIED: London, UK, 2014; ISBN 978-1-78431-006-6.

26. Guarín, A. The value of domestic supply chains: Producers, wholesalers, and urban consumers in Colombia. Dev. Policy Rev. 2013, 31, 511-530. [CrossRef]

27. Vorley, B. Markets for the many rather than the few. Rural 21 Int. J. Rural Dev. 2013, 47, 28-29.

28. Dolan, C.; Humphrey, J. Changing governance patterns in the trade in fresh vegetables between Africa and the United Kingdom. Environ. Plan. A 2004, 36, 491-509. [CrossRef]

29. Reardon, T.; Gulati, A. The Supermarket Revolution in Developing Countries—Policies for “Competitiveness with Inclusiveness. In IFPRI Policy Brief 2; International Food Policy Research Institute: Washington, DC, USA, June 2008; Available online: http:/ / www.ifpri.org/pubs/bp/bp002.asp (accessed on 18 August 2018).

30. Reardon, T.; Henson, S.; Berdegué, J. 'Proactive fast-tracking' diffusion of supermarkets in developing countries: Implications for market institutions and trade. J. Econ. Geogr. 2007, 7, 399-431. [CrossRef]

31. Rao, E.; Brümmer, B.; Qaim, M. Farmer participation in supermarket channels, production technology, and efficiency: The case of vegetables in Kenya. Am. J. Agric. Econ. 2012, 94, 891-912. [CrossRef]

32. Rao, E.; Qaim, M. Supermarkets and agricultural labor demand in Kenya: A gendered perspective. Food Policy 2013, 38, 165-176. [CrossRef]

33. Michelson, H. Small farmers, NGOs, and a Walmart world: Welfare effects of supermarkets operating in Nicaragua. Am. J. Agric. Econ. 2013, 95, 628-649. [CrossRef]

34. Michelson, H.; Reardon, T.; Perez, F. Small farmers and big retail: Trade-offs of supplying supermarkets in Nicaragua. World Dev. 2011, 40, 342-354. [CrossRef]

35. Miyata, S.; Minot, N.; Hu, D. Impact of contract farming on income: Linking small farmers, packers, and supermarkets in China. World Dev. 2009, 37, 1781-1790. [CrossRef] 
36. Reardon, T. The global rise and impact of supermarkets: An international perspective. In The Supermarket Revolution in Food: Good, Bad or Ugly for the World's Farmers, Consumers and Retailers? Proceedings of the Crawford Fund 17th Annual Parliamentary Conference, Canberra, Australia, 14-16 August 2011; Milligan, A., Brown, A.G., Eds.; The Crawford Fund: Fyshwick, Australia; pp. 14-29. Available online: https://www. crawfordfund.org/wp-content/uploads/2014/02/2011AnnualConferenceProceedings.pdf (accessed on 18 August 2018).

37. Gereffi, G. The organisation of buyer-driven global commodity chains: How U.S. retailers shape overseas production networks. In Commodity Chains and Global Capitalism; Gereffi, G., Korzeniewicz, M., Eds.; Praeger: Westport, CT, USA, 1994; pp. 95-122.

38. Humphrey, J.; Schmitz, H. How does insertion in global value chains affect upgrading in industrial clusters? Reg. Stud. 2002, 36, 1017-1027. [CrossRef]

39. Lee, J.; Gereffi, G.; Beauvais, J. Global value chains and agrifood standards: Challenges and possibilities for smallholders in developing countries. Proc. Natl. Acad. Sci. USA 2010, 109, 12326-12331. [CrossRef]

40. Legge, A.; Orchard, J.; Graffham, A.; Greenhalgh, P.; Kleih, U.; Macgregor, J. Mapping different supply chains of fresh produce exports from Africa to the UK. In Fresh Perspective-Agrifood standards and pro-poor growth in Africa; IIED: London, UK, April 2008; Issue 12; Available online: https:/ / assets.publishing.service. gov.uk/media/57a08ba940f0b652dd000df8/60506-fp12.pdf (accessed on 18 August 2018).

41. UNCTAD. Global Value Chains: Investment and Trade for Development; UNCTAD: New York, NY, USA; Geneva, Switzerland, 2013.

42. Yin, R.K. Case Study Research: Design and Methods, 3rd ed.; SAGE: Thousand Oaks, CA, USA, 2003.

43. Sterns, J.A.; Schweikhardt, D.B.; Peterson, J.C. Using case studies as an approach for conducting agribusiness research. Int. Food Agribus. Manag. Rev. 1998, 1, 311-327. [CrossRef]

44. Natawidjaja, R.; Rasmikayati, E.; Kharisma, B.; Kusnandar; Purwanto, D.; Reardon, T. Restructuring of Agrifood Chains in Indonesia: National and Local Meso Study Report; Regoverning Markets Agrifood Sector Studies; International Institute for Environment and Development: London, UK, 2007.

45. World Bank. Horticultural Producers and Supermarket Development in Indonesia; World Bank Report No. 38543; World Bank: Washington, DC, USA, 2007; Available online: http:/ / documents.worldbank.org/curated/en/ 863941468752426320/Horticultural-producers-and-supermarket-development-in-Indonesia (accessed on 18 August 2018).

46. Dewalt, K.M.; Dewalt, B.R.; Wayland, C.B. Participant Observation. In Handbook of Methods in Cultural Anthropology; Bernard, H.R., Ed.; Altamira Press: Lanham, MD, USA; Boulder, CO, USA; New York, NY, USA, 1998; pp. 259-299.

47. Tempo. Prospering from Agrobusiness. Tempo 1305. 30 September 2012, pp. 48-58. Available online: https:/ / magz.tempo.co/read/25452/prospering-from-agrobusiness (accessed on 20 October 2012).

48. Sunanto, S. The Effects of Modern Food Retail Development on Consumers, Producers, Wholesalers and Traditional Retailers: The Case of West Java. Doctoral Dissertation, Erasmus University Rotterdam, Rotterdam, The Netherlands, 2013. Available online: http://hdl.handle.net/1765/41067 (accessed on 18 August 2018).

49. Chowdhury, S.; Gulati, A.; Gumbira-Said, E. High Value Products, Supermarkets and Vertical Arrangements in Indonesia; Markets, Trade and Institutions Division Discussion Paper No. 83; International Food Policy Research Institute: Washington, DC, USA, 2005.

50. Euromonitor. Grocery retailers in Indonesia. January 2017. Retrieved from Euromonitor Passport Database. Available online: https:/ / www.portal.euromonitor.com/portal/account/login (accessed on 18 August 2018).

51. Daneshkhu, S. Carrefour Exits Indonesian Business. Financial Times. 20 November 2012. Available online: https:/ / www.ft.com/content/9a922848-3305-11e2-aabc-00144feabdc0 (accessed on 18 August 2018).

52. Lotte Mart. Global Lotte Mart That is Advancing towards Our Customers and the World. Available online: https:/ / company.lottemart.com/eng/about02.html (accessed on 18 August 2018).

53. Vetter, T.; Larsen, M.N. "Supermarkedsrevolutionen" i Indonesien ["Supermarket Revolution" in Indonesia]. Geogr. Orienter. 2014, 44, 28-32. (In Danish)

54. Carrefour Indonesia. Highlights of Activities and Initiatives in 2006 (Company Brochure); Carrefour: Jakarta, Indonesia, 2016.

55. Euromonitor. Grocery retailers in Indonesia. March 2015. Retrieved from Euromonitor Passport Database. Available online: https:/ / www.portal.euromonitor.com/portal/account/login (accessed on 28 April 2016). 
56. Dyck, J.; Woolverton, A.E.; Rangkuti, F.Y. Indonesia's Modern Food Retail Sector: Interaction with Changing Food Consumption and Trade Patterns; Economic Information Bulletin No. 97; US Department of Agriculture, Economic Research Service: Washington, DC, USA, 2012.

57. Rangkuti, F.Y.; Wright, T. Indonesia-Retail foods—Indonesia Retail Report Update 2013; GAIN Report No. ID1358; USDA Foreign Agricultural Service: Jakarta, Indonesia, 2013. Available online: http:/ / gain.fas.usda. gov /Recent\%20GAIN\%20Publications /Retail\%20Foods_Jakarta_Indonesia_12-13-2013.pdf (accessed on 18 August 2018).

58. FAOSTAT. Crops and Livestock Products [Import Figures for Selected Fresh Fruits and Vegetables in Indonesia, 1997-2011]. Available online: http:/ / www.fao.org/faostat/en/\#data/TP (accessed on 12 January 2014).

59. Tempo. Fruit Imports: Closed Here, Expensive There. Tempo. 12 May 2013, pp. 40-41. Available online: https:/ / magz.tempo.co/read/26532/ closed-here-expensive-there (accessed on 11 October 2013).

60. Ponte, S.; Ewert, J. Which way is "up" in upgrading? Trajectories of change in the value chain for South African wine. World Dev. 2009, 37, 1637-1650. [CrossRef]

61. Bair, J. Global capitalism and commodity chains: Looking back, going forward. Compet. Chang. 2005, 9, 153-180. [CrossRef]

62. Bolwig, S.; Ponte, S.; Du Toit, A.; Riisgaard, L.; Halberg, N. Integrating poverty and environmental concerns into value chain analysis: A conceptual framework. Dev. Policy Rev. 2010, 28, 173-194. [CrossRef]

63. Coe, N.M.; Dicken, P.; Hess, M. Global production networks: Realizing the potential. J. Econ. Geogr. 2008, 8, 271-295. [CrossRef]

(C) 2019 by the authors. Licensee MDPI, Basel, Switzerland. This article is an open access article distributed under the terms and conditions of the Creative Commons Attribution (CC BY) license (http:/ / creativecommons.org/licenses/by/4.0/). 